\title{
MENINGKATKAN KUALITAS PENDIDIK TERHADAP ADMINISTRASI PERSONALIA PENDIDIKAN
}

\author{
Yusup \\ Program Studi Pendidikan IPS \\ Fakultas Keguruan dan Ilmu Pendidikan \\ Univeritas Lambang Mangkurat \\ Banjarmasin \\ E-Gmail : 201012821007@Mhs.ulm.ac.id
}

\begin{abstract}
Abctract
Dunia Pendidikan memiliki berbagai permasalahan salah satuya ialah terhadap kualitas pendidik. Maka perlu meningkatkan kualitas pendidik untuk keberhasilan pendidikan formal dalam menjalankan proses pendidikan dan pada saat efektivtas dengan tanggung jawab dalam melaksanakannya dalam melayani dengan pengunaaan sumber dana yang efesien. kompetensi yang harus dimiliki oleh peserta didik, yakni memiliki kemampuan berkomunikasi, berpikir jernih dan kritis, kemampuan mempertimbangkan segi moral suatu permasalahan, menjadi warga negara yang efektif, dan toleran terhadap pandangan yang berbeda.
\end{abstract}

\section{Keywords: Pendidik, Adimintarasi Personalia Pendidikan.}

\section{Pendahuluan :}

Dalam dunia pendidikan memiliki pencapaian untuk meningatkan kualitas dan mutu yang sesuai dengan tujuan pendidikan dari dukungan seluruh kompenen pendidikan dalam keberhasilannya. Suatu pusat pendidikan dari pemikiran efensiensi da efektivitas dalam penyelanggarkaan pendidikan kepada warga masyarakat yakni salah satunya peserta didik. Dengan adanya manajemen atau pengelola sebagai kompenen intergal pada proses pendidikan secara keseluruhan yang bertujuan dapat terwujudnya pendidikan itu akan optimal, efektif dan efesien. Suatu manajemen admintrasi personalia sangat berperan dalam keberhaslan suatu proses pendidikan sebab serangkaian proses kerja sama mulai dari perencanaan, pengorganisasian, penggerakan dan pengawasan dalam bidang personalia dengan mendayagunakan sumber yang ada secara efektif dan efisien, sehingga semua personil sekolah menyumbang secara optimal bagi pencapaian tujuan pendidikan atau sekolah yang telah ditetapkan.

Untuk mencapai lembaga pendidikan yang bermutu, maka lembaga pendidikan tersebut perlu memiliki pengelolaan administrasi sekolah yang baik. Administrasi pendidikan mencangkup semua kegiatan yang lazim disebut dengan penataan, pengaturan, pengelolaan pendidikan. Aktivitas tersebut menyangkup segenap kegiatan penataan atau pengaturan untuk menjalin kerja sama kelompok orang untuk mencapai tujuan seperti guru dan karyawan. Kegiatan berikut meliputi berbagai pekerjaan seperti mengatur, menyertakan, memimpin, memerintah, mendayagunakan fasilitas, mengatur keuangan, dan surat menyurat agar semua kegiatan dapat berjalan harmonis, efesien dan efektif. Secara garis besar komponen-komponen administrasi dapat digolongkan menjadi administrasi personil sekolah, administrasi kurikulum, sarana dan prasarana pendidikan, administrasi siswa, administrasi sekolah dan masyarakat. Administrasi personalia sendiri mencakup: perencanaan pegawai, pengadaan pegawai, 
pembinaan dan pengembangan pegawai, promosi dan mutasi, pemberhentian pegawai, kompensasi, penilaian pegawai. Salah satu tujuan dari pada itu adalah guna meningkatkan mutu pendidikan atau mutu sekolah yang tertuju pada mutu lulusan. Merupakan hal yang sulit untuk sekolah menghasilkan lulusan yang bermutu, jika tidak melalui proses yang bermutu. Begitu juga sebaliknya, proses pendidikan yang bermutu jika tidak di dukung oleh administrator, guru, konselor serta tata usaha yang bermutu dan professional maka sulit untuk mencapai tujuannya.

Pendidikan ialah aktivitas atau usaha manusia untuk menumbuh kembangkan potensipotensi bawaan peserta baik jasmani maupun rohani untuk memperoleh hasil dan prestasi. Personalia ialah orang yang menjalankan sesuatu tugas untuk mencapai tujuan dalam hal ini di sekolah dibatasi dengan sebutan pegawai. Maka dari itu personil di sekolah tentu saja meliputi unsur guru atau pendidik sebagai tenaga edukatif dan unsur karyawan yang disebut tenaga administratife. Keseluruhan personil sekolah ialah kepala sekolah, guru, pegawai administrasi (TU) dan pesuruh penjaga sekolah. Pada proses kegiatan di sekolah maka unsur manusia merupakan unsur penting, karena kelancaran jalannya pelaksanaan program sekolah sangat ditentukan oleh manusia-manusia yang menjalankannya. Dan juga bagaimanapun lengkap dan baik fasilitas yang berupa gedung, perlengkapan, alat kerja, metode-metode kerja, dan dukungan masyarakat akan tetapi apabila manusia-manusia yang bertugas menjalankan program sekolah itu kurang berpartisipasi, maka akan sulit untuk mencari tujuan pendidikan yang diharapkan. Kepala sekolah wajib mendayagunakan seluruh personil secara efektif dan efisien agar tujuan penyelenggarakan pendidikan di sekolah tersebut tercapai secara optimal. Pendayagunaan ini ditempuh dengan jalan memberikan tugastugas jabatan sesuai dengan kemampuan dan kewenangan masing-masing individu. Oleh karena itu adanya "job description" yang jelas sangat diperlukan.

Kualitas/mutu pendidik dan tenaga kependidikan dapat dilihat dari kualifikasi akademik, kompetensi, sertifikasi sesuai dengan bidang tugasnya, serta sehat jasmani dan rohani, serta memiliki kemampuan untuk mewujudkan pendidikan nasional. Kualifikasi akademik yang dimaksud adalah pendidikan tinggi progam sarjana atau diploma empat. Kompetensi pendidik yang dimaksud adalah kompetensi pedagogik, kompetensi kepribadian, kompetensi sosial, dan kompetensi profesional.

Kualitas Pendidik dan Tenaga Kependidikan Pada pengelolaan pendidikan yang sentralistik, sekolah menjadi unit birokrasi dan pendidik sering diposisikan sebagai karyawan birokrasi pemerintah. Sebaliknya pada format pengelolaan pendidikan yang desentralisasikan, sekolah dikonsepkan sebagai unit akademik dan pendidik merupakan tenaga profesional. Supaya mempunyai lulusan peserta didik yang diharapkan maka sekolah harus bisa meningkatkan kualitas/mutu pendidik dan tenaga kependidikannya. Untuk meningkatkan kualitas/mutu pendidik dan tenaga kependidikan setiap sekolah biasanya mempunyai cara yang berbeda-beda, akan tetapi disini penulis akan membahas pengertian kualitas/mutu terlebih dahulu. Pada dasarnya kualitas sama dengan mutu. Pengertian mutu pada konteks pendidikan mengacu pada masukan, proses, keluaran, dan dampaknya.

Administrasi pendidikan merupakan perpaduan dari dua kata yakni "administrasi" dan "pendidikan" yang masing-masing dari kata tersebut memiliki arti tersendiri, tetapi bila di rangkaikan membentuk arti baru. Pada hakikatnya, administrasi pendidikan merupakan penerapan ilmu administrasi dalam dunia pendidikan atau pembinaan, pengembangan dan pengendalian usaha praktekpraktek pendidikan. Hadari Nawawi mengatakan, administrasi 
pendidikan adalah rangkaian kegiatan atau keseluruhan proses pengendalian usaha kerja sama sejumlah orang untuk mencapai tujuan pendidikan secara sistematis yang diselenggarakan dalam lingkungan tertentu, terutama dalam lembaga pendidikan formal. Ada perbedaan antara administrasi pendidikan dan kegiatan operasional kependidikan. Kegiatan operasional kependidikan adalah kegiatan-kegiatan edukattif seperti kegiatan belajar mengajar, bimbingan dan penyuluhan sebagainya. Pengertian Administrasi Personalia Pendidikan Administrasi personalia atau administrasi personil sekolah adalah salah satu kegiatan yang direncanakan oleh para pegawai disekolah secara berkesinambungan yang dapat membantu dan menunjang kegiatan-kegiatan sekolah khususnya proses belajar mengajar (PBM) secara efektif dan efesien demi tercapainya tujuan pendidikan yang telah ditetapkan. Apra personil harus dikelola dengan baik agar mereka senantiasa aktif dan bergairah dalam menjalankan tugasnya sehari-hari.

Kompetensi yang harus dimiliki oleh peserta didik, yakni memiliki kemampuan berkomunikasi, berpikir jernih dan kritis, kemampuan mempertimbangkan segi moral suatu permasalahan, menjadi warga negara yang efektif, dan toleran terhadap pandangan yang berbeda. Peningkatan ini dipengaruhi oleh kemampuan guru untuk meningkatkan motivasi belajar peserta didik melalui pemilihan apersepsi yang tepat. Peningkatan kualitas pembelajaran yang dimaksud mengindikasikan adanya komunitas pembelajaran yang baik. Di samping itu, peserta didik mendapatkan kemampuan berpikir historis. Kemampuan ini nampak pada saat peserta didik mampu menyimpulkan materi dengan memberikan analogi serta konteks yang diutarakan kronologis dan kontekstual

Menurut Hendrat Soetopo (1989: 174), Administrasi personalia ialah administrasi yang menangani masalah-masalah kepegawaian dalam suatu badan usaha atau lembaga. Sedangkan menurut Suharsimi (1990: 79) mengartikan administrasi personal atau administrasi kepegawaian ialah segenap proses penataan yang bersangkut paut dengan masalah memperoleh dan menggunakan tenaga kerja untuk dan disekolah dengan efisien, demi tercapainya tujuan sekolah yang telah ditentukan sebelumnya.

Pembelajaran dimaknai sebagai proses pendidikan dimana memberikan ruang (kesempatan) peserta didik mengembangkan segala potensi diri. Kemampuan merujuk pada aspek, yaitu: sikap, pengetahuan, dan keterampilan. Ketiganya sangat dibutuhkan bagi diri peserta didik untuk hidup bermasyarakat, berbangsa, serta berkontribusi pada kesejahteraan. Pembelajaran diarahkan pada pemberdayaan potensi peserta didik agar menjadi satu kompetensi yang ideal. Prinsipil, ini dikhususkan sebagai proses pengembangan potensi kemampuan yang semakin lama terus meningkat nantinya. Demikian, diperlukan satu cara inovatif agar peserta didik memahami segala potensi yang ada didirinya. (Mutiani, M., Sapriya, S., Handy, M. R. N., Abbas, E. W., \& Jumriani, J. (2021).

\section{Metode}

Artikel ini bersifat desktiptif dengan uraian narasi terstruktur. Artikel juga ditulis dengan menggunakan studi literatur. Studi literatur dipahami sebagai rangkaian aktivitas terkait pengumpulan data berdasarkan sumber pustaka, membaca, dan mencatat, hingga mengolah bahan-bahan dari sumber sekunder (Snyder, 2019). Dalam mencari literatur, dimanfaatkan mesing pencarian (search engine) di beberapa situs, seperti salah satunya ialah sholar. 


\section{Pembahasan}

Dalam sebuah kelembagaan atau instansi apapun administrasi merupakan faktor yang sangat penting untuk keteraturan kegiatan yang akan mempengaruhi kemajuan instansi tersebut. Administrasi pendidikan sangat penting dalam mempersiapkan situasi belajar di sekolah, agar pendidikan dan pengajaran berlangsung dengan baik sesuai dengan tujuan diperlukan peningkatan dan penyempurnaan penyelenggaraan sistem pendidikan yang sesuai dengan kebutuhan dan teknologi yang berkembang pada masyarakat yang sesuai dengan kebutuhan dan teknologi serta penyediaan sarana dan prasarana pendidikan yang memadai agar tujuan pendidikan dapat tercapai untuk mencetak generasi yang berkualitas.

Dalam undang-undang tentang Sistem Pendidikan Nasional Nomor 14 tahun 2005, yang menyatakan; "Bahwa pembangunan nasional dalam bidang pendidikan adalah supaya mencerdaskan kehidupan bangsa dan meingkatkan kualitas manusia Indonesia yang beriman dan bertakwah dan berahlak mulia serta menguasai ilmu pengetahuan, teknologi dan seni dalam mewujudkan masyarakat yang maju, adil, makmur dan beradab berdasarkan Pancasila.

Administrasi personalia merupakan seluruh proses kegiatan yang direncanakan dan diusahakan secara sengaja dan bersungguh-sungguh serta pembinaan secara kontinu para pegawai di sekolah, sehingga mereka dapat melaksanakan kegiatan-kegiatan sekolah (khususnya proses belajar mengajar) secara efektif dan efisien demi tercapainya tujuan pendidikan yang telah ditetapkan (Ari H Gunawan, 1998: 21). Manajemen pendidikan merupakan alternatif strategis untuk meningkatkan kualitas pendidikan. Manajemen sekolah secara langsung akan mempengaruhi dan menentukan efektif tidaknya kurikulum, berbagai peralatan belajar, waktu mengajar, dan proses pembelajaran. Administrasi adalah suatu bentuk usaha dan aktivitas yang berhubungan dengan pengaturan kebijakan agar dapat mencapai target/tujuan organisasi. Jadi dapat dikatakan bahwa administrasi punya peranan yang sangat krusial dalam semua aktivitas sebuah organisasi. Dalam arti sempit administrasi adalah segala sesuatu bentuk kegiatan tata usaha yang meliputi kegiatan-kegiatan ketatausahan yang mencakup korespondensi, kesekretariaan, penyususan laporan dan kearsipan.

Pendidikan ialah suatu hasil peradaban bangsa yang dikembangkan atas dasar pandangan hidup bangsa Indonesia. Karenanya bagaimanapun peradaban suatu masyarakat, di dalamnya berlangsung dan terjadi suatu proses pendidikan generasi milenial sebagai usaha manusia untuk melestarikan hidupnya. Pendidikan bagi kehidupan manusia merupakan kebutuhan mutlak yang harus di penuhi sepanjang hayat. Menurut Paputungan, N. (2020). Pendidikan (education) secara semantuk berasal dari Bahasa yunani paidagogia yang berarti pergaulan dengan anak-anak pedagogos adalah seorang nelayan atau bujang dalam zaman yunani kuno yang pekerjaannya menjemput dan mengantar anak anak ke dan dari sekolah. Menurut Langeveld pendidikan adalah setiap usaha, pengaruh, perlindungan dan bantuan yang diberikan kepada anak yang tertuju yang terjudu pada pendewasaan anak itu, atau lebih tepat membantu anak agar cukup, cakap melaksanakan tugas hidupnya sendiri.

Dengan diberlakukannya Peraturan Pemerintah No. 32 tahun 2013 tentang perubahan atas Peraturan Pemerintah No. 19 tahun 2005 tentang Standar Nasional Pendidikan (SNP) Pasal 1 Ayat 8 Standar Pendidik dan Tenaga Kependidikan adalah kriteria mengenai pendidikan prajabatan dan kelayakan maupun mental, serta pendidikan dalam jabatan. Dalam upaya untuk 
meningkatkan mutu dan kualitas lembaga Lembaga pendidikan Islam, serta dalam upaya menjawab tantangan zaman yang semakin kompleks dan sangat mendesak, maka akan lebih tepat apabila lembaga pendidikan Islam harus mengadakan pembaharuan dan pengembangan terhadap sistem pendidikan tersebut. Namun demikian, performa pendidikan Islam sampai saat ini masih sangat rendah, dan diantara penyebabnya adalah karena pengelolaan atau manajerial serta kebijakan yang belum terorganisir dengan baik. Untuk itu, kemudian diperlukan adanya upaya yang lebih dari para pengelola. Dalam hal ini tentu erat kaitannya dengan profesionalisme manajemen personalianya dalam rangka mengembangkan lembaga pendidikan Islam, agar dapat menjawab berbagai tuntutan dalam pendidikan.

Pendidik Ialah sosok yang menjadi tokoh, panutan, dan identifikasi bagi para peserta didik dan lingkungannya. Oleh karena itu pendidik harus memiliki standar kualitas pribadi tertentu yang mencakup tanggung jawab wibawa, mandiri dan disiplin. Menurut UndangUndang RI No. 14 tahun 2005 pasal 1(1) yang dimaksud "guru yaitu pendidik profesional dengan tugas utama mendidik, mengajar, membimbing, mengarahkan, melatih, menilai dan mengevaluasi peserta didik pada pendidikan usia dini jalur pendidikan formal, pendidikan dasar, pendidikan menengah". Pada pasal 39 ayat 2 Undang-Undang Sistem Pendidikan Nasional, menyatakan pendidik merupakan tenaga profesional yang bertugas merencanakan dan melaksanakan proses pembelajaran, menilai hasil pembelajaran, melakukan pembimbingan dan pelatihan, serta melakukan penelitian dan pengabdian kepada masyarakat, terutama bagi pendidik pada perguruan tinggi. 10 Pada pasal 1 ayat 5 UU Sistem Pendidikan Nasional dijelaskan bahwa "Tenaga Kependidikan adalah anggota masyarakat yang mengabdikan diri dan diangkat untuk menunjang penyelenggaraan pendidikan". Dan tenaga kependidikan bertugas melaksanakan administrasi, pengelolaan, pengembangan, pengawasan, dan pelayanan teknis untuk menunjang proses pendidikan pada satuan pendidikan.

Administrasi personalia adalah suatu kegiatan yang direncanakan oleh para pegawai disekolah, administrasi personalia iala semua anggota yang bekerja untuk kepentingan untuk mencapai tujuan. Perosnil organisasi pendidikan mencangkup para guru, para pegawaia wakil, siswa atau mahasiswa dan para alumni. kegiatan-kegiatan yang menyangkut administrasi personil yaitu pengadaan,pengembangan, pemberian kompensasi, promosi dan mutasi, pemberhentian pegawai, penilaian pegawai. agar tercapai diberbagai tujuan individu, organisasasi dan masyarakat. Jelaslah bahwa yang dimaksud administrasi personil adalah tenaga edukattif (guru) dan tenaga administrative (non guru).

Manajemen personalia adalah perencanaan, pengorganisasian, pengarahan, dan pengawasan kegiatan-kegitan, pengadaan, pengembangan dan pemberian kompensasi, pengintegrasian, pemeliharaan dan pelepasan sumberdaya manusia agar tercapai berbagai tujuan individu dan organisasi dalam masyarakat. Sedangkan Paputungan, N. (2020). Manajemen adalah proses bekerja sama antara individu dan kelompok serta sumber daya lainnya dalam mencapai tujuan organisasi adalah sebagai aktvitas manejerial. Manajemen dalam artian sempit sebagai penyusunan dan pencatatan harga dan informasi secara sistematis dengan tujuan supaya dapat menyediakan keterangan serta memudahkan memperolehnya kembali secara keseluruhan dalam hubungan satu dan lainnya.

Manajemen Personalia merupaakan Istilah personalia, personil atau kepegawaian yang mengandung arti keseluruhan orang-orang yang bekerja pada suatu organisasi. Dengan demikian manajemen personalia adalah manajemen yang menitik beratkan perhatiannya 
kepada soal-soal pegawai atau personalia didalam suatu organisasi. Menurut Made Pidarta, personalia ialah semua anggota yang bekerja untuk kepentingan organisasi yaitu untuk mencapai tujuan yang sudah ditentukan. Personalia organisasi pendidikan mencakup para guru, para pegawai, para wakil siswa atau mahasiswa, dan para alumnus, termasuk juga para manajer pendidikan. Menurut Suryo Subroto personalia atau personil ialah orang-orang yang melaksanakan suatu tugas untuk mencapai tujuan. Dalam hal ini di sekolah dibatasi dengan sebutan pegawai. Oleh karena itu personil sekolah tentu saja meliputi unsur guru yang disebut tenaga edukatif dan unsur karyawan yang disebut tenaga administratif. Jadi manajemen personalia ialah pengognaisaian, perencanaan, pengawasan, pengarahan, kegiatan-kegiatan dan pengadaan, pengembangan, pemberian kompensasi pengintegrasian dan pemeliharaan, agar tercapai diberbagai tujuan individu, organisasi dan masyarakat.

Peranan personalia dalam suatu organisasi, termasuk sekolah sangat penting. Namun personalia pendidikan akan optimal jika dikelola dengan baik. Pimpinan lembaga pendidikan memiliki peran sangat sentral dalam mengelola personalia lembaga, sehingga sangat penting bagi pimpinan untuk memahami dan menerapkan pengelolaan personalia dengan baik sehingga tujuan pendidikan dapat dicapai secara optimal. Manajemen personalia adalah merupakan bagian terpenting dari manajemen pendidikan, manajemen personalia memiliki peran penting dalam rangka pengembangan suatu lembaga. Karena manajemen personalia sendiri berhubungan dengan individu-individu yang ada dalam lembaga yang menjalankan sistem, terutama para tenaga kependidikan yang langsung bertugas di lapangan dengan tuntutan tinggi, yaitu mencetak out put yang berkualitas sehingga akan terus mendukung program yang dicanangkan oleh lembaga pendidikan unggulan. Suatu organisasi apapun bentuknya tidak akan mampu berjalan dengan baik jika tidak diimbangi dengan sistem manajerial yang baik, terutama manajemen personalia. Karena manusia adalah unsur terpenting yang harus ada dalam suatu organisasi, terlebih organisasi pendidikan, dimana pada organisasi ini baik subjek maupun objeknya adalah manusia. Jika suatu organisasi memiliki dana yang besar, fasilitas yang memadai dan juga lingkungan yang mendukung, namun tidak didukung oleh personalia yang teratur dengan baik, maka dapat dipastikan bahwa kelangsungan dari suatu organisasi tersebut tidak akan lama. Jadi dalam manajemenpersonalia harus ada pembagian tanggung jawab yang jelas, tegas dan tepat sehingga program yang ditetapkan dapat berjalan dengan suatu sistem, agar semua pegawai mau bekerja dan menjalankan tugas yang dibebankan kepada yang bersangkutan

Fungsi personalia di atas dilaksanakan dan dikerjakan oleh manajer atau pimimpin. Manajer memperoleh hasil dari bawahannya, dan agar bawahannya dapat berprestasi besar dan cakap bekerja, maka para pemimpin harus memberi perhatian kepada hal-hal yang berhubungan dengan fungsi personalia.

Prinsip-prinsip Personalia dalam Organisasi Menurut Ngalim Purwanto personalia dalam suatu organisasi harus memiliki prinsip-prinsip atau ciri-ciri yaitu:

a) Memiliki tujuan yang jelas.

b) Tiap anggota dapat memahami dan menerima tujuan tersebut.

c) Adanya kesatuan arah sehingga dapat menimbulkan kesatuan tindak dan kesatuan pikiran.

d) Adanya kesatuan perintah.

e) Adanya keseimbangan antara wewenang dan tanggung jawab masingmasing anggota. 
f) Adanya pembagian tugas atau pekerjaan sesuai dengan kemampuan, keahlian, dan bakat masing-masing, sehingga dapat menimbulkan kerjasama yang harmonis.

g) Adanya jaminan keamanan dalam bekerja. h. Adanya gaji yang setimpal dengan jasa atau pekerjaan.

h) Garis-garis kekuasaan dan tanggung jawab serta tata kerjanya jelas tergambar dalam struktur organisasi.

Oleh karena itu supaya kegiatan personalia dalam organisasi dapat berjalan lancar, serta personalia dapat bekerja secara efektif maka antara manajer dan bawahan dapat melaksanakan prinsip-prinsip tersebut sesuai dengan jabatan dan kedudukan.

Setrategi Pengelolaan Kegiatan Yang Mendukung Peningkatan Kualitas Personalia yakni dalmPengadaan Personalia atau Pegawai Pengadaan pegawai merupakan proses kegiatan untuk mengisi formasi atau tempat serta jabatan yang kosong dan juga pengadaan pegawai dikarenakan adanya perluasan organisasi. Dilingkungan lembaga pendidikan, tenaga kerja atau pegawai dapat dibedakan menjadi dua kelompok, yaitu:

a) Tenaga teknisi atau tenaga professional atau tenaga edukatif/guru/dosen/pengajar, yakni personal pelaksana proses belajar mengajar dan kegiatan kependidikan lainnya.

b) Tenaga administratif atau tenaga non edukatif/non guru/ non dosen, yakni personal yang tidak langsung bertugas mewujudkan proses belajar mengajar, antara lain meliputi pegawai TU, pegawai laboratorium, keuangan, sopir, pesuruh, jaga malam, pegawai perpustakaan dan lainlain.

Untuk memelihara efektivitas kerja, pada saat penerimaan dan penempatan pegawai harus diperhatikan persyaratan tuntutan jenis sifat pekerjaan, ketrampilan, pengetahuan dan pengalaman pegawai. Untuk itu dilingkungan setiap lembaga pendidikan diperlukan kegiatan analisis pekerjaan (job analysis) untuk menyusun deskripsi pekerjaan (job description) dan klasifikasi pekerjaan (job classification), agar pada saat penerimaan dan penempatan pegawai dapat disesuaikan antara pegawai yang diperlukan dengan tuntutan jenis dan sifat pekerjaan. Dalam rangka pengadaan personil atau rekrut personil terutama guru, banyak cara yang dapat dipakai, yaitu:

a) Spoils systems, yaitu system pengadaan personil yang didasarkan pada kesamaan kepartaian, dalam arti pengisian pekerjaan atau jabatan yang ada diusahakan teman separtai, tanpa atau kurang memperhatikan apakah kandidat memenuhi kualifikasi atau tidak.

b) Nepotism systems yaitu cara mengadakan personil yang didasarkan pada hubungan kekeluargaan.

c) Menit systems yakni cara pengadaan personil berdasarkan kecakapan yang dimiliki.

d) Career systems yakni cara pengadaan personil yang pada awalnya didasarkan pada kecakapan sedang pada proses lanjut, selain kecakapan pada masa kerja, loyalitas dan syarat kerja lainnya turut mendukung.

e) Sistem prestasi, cara ini terutama berlaku bagi personil lama yang hendak naik pangkat atau hendak menduduki jabatan yang lebih tinggi. Kenaikan pangkat didasarkan pada kecakapan dan prestasi kerja yang dimiliki. Kecakapan dibuktikan dengan lulus ujian sedang prestasi dibuktikan dengan melalui karya nyata. 
Jadi dari pembahasan diatas bahwa penerimaan dan penempatan pegawai harus memperhatikan kualifikasi para individu dari pegawai tersebut. Dalam penerimaan dan penempatan pegawai yang tidak tepat, menimbulkan berbagai kerugian dan masalah karena setiap pekerjaan yang dilimpahkan tidak akan terselesaikan secara efektif, dengan demikian tenaga dan waktu akan terbuang-buang, bahkan mungkin pula menjadi pemborosan karena biaya dipergunakan untuk personil yang tidak mampu mencapai prestasi seperti yang diharapkan.

Pengembangan Personalia Pengembangan personalia ialah tata cara atau peninjauan kembali untuk menjamin stabilitas kepegawaian. Perkembangan personal merupakan salah satu kegiatan penting bagi kemajuan sekolah. Keberhasilan program pengembangan personal, di dalam beberapa hal banyak dipengaruhi oleh peranan pimpinannya. Mereka diperlukan mulai dari tahap perencanaan, pelaksanaan dan penyelesaian pogram itu. Walaupun pimpinan sudah memberikan kesempatan baik dalam menyediakan fasilitas secukupnya, itu semua belum cukup masih ada yang diperlukan dari dia, yaitu kemauan, keseriusan dan kesungguhan dalam melaksanakan. Dengan singkat dapat dikatakan bahwa manajemen pimpinan merupakan kunci untuk program pengembangan personal ini.

Sebab-sebab dilaksanakannya pengembangan personalia menurut Lailiyah, N. (2017). Yakni : Adanya tata cara atau peraturan baru dalam personalia tersebut. Adanya pegawai yang kurang cakap. Adanya mesin-mesin baru. Perlunya penyegaran kembali khususnya pegawai. Tata cara peningkatan mutu karyawan Peningkatan mutu karyawan dapat dilakuan dengan diadakan suatu latihan dan pendidikan. Latihan ialah suatu kegiatan atau usaha untuk meningkatkan pengetahuan dan ketrampilan seorang pegawai dalam melaksanakan tugas atau pekerjaan tertentu. Latihan yang dilakukan oleh personalia atau pegawai bertujuan agar pegawai bekerja lebih efisien. Selain itu, latihan ini juga dilakukan agar pegawai dapat mengembangkan keahliannya, sehingga pekerjaan apat diselesaikan dengan lebih cepat dan efisien, serta mengembangkan sikap dan pengetahuan pegawai. Latihan dan pendidikan dapat diberikan dengan cara: Dengan penjelasan dan contoh-contoh kerja dan training. Dengan sistem individual atau klasikal. Dengan rapat. Lokakarya (penjelasan dan pameran). Briefing (penjelasan yang bersifat instruksi) Pembinaan dan pengembanan terhadap staf tidak hanya pada anggota yang baru saja, tetapi juga kepada seluruh staf. Pembinaan harus dilakukan secara terus menerus dan secara sistematis. Pembinaan ini sangat penting karena perkembangan baik perkembangan ilmu pengetahuan, perkembangan teknologi, maupun perkembangan masyarakat dan kebijaksanaan-kebijaksanaan yang baru.

Kesejahteraan Personalia untuk meningkatkan kegairahan bekerja dan menjamin hari tua diselenggarakan usaha peningkatan kesejahteraan pegawai. Peningkatan kesejahteraan tersebut harus diusahakan secara bertahap sesuai dengan kemampuan sehingga pada akhirnya pegawai dapat memusatkan perhatian sepenuhnya untuk melaksanakan tugasnya. Dalam meningkatkan kesejahteraan para anggota organisasi memang merupakan salah satu tugas manajer. Organisasi adalah merupakan salah satu bentuk kehidupan bersama dengan tujuan tertentu yang sudah disepakati bersama. Untuk mencapai tujuan itu, para manajer perlu mengarahkan, membina, dan mengkoordinasi anggota-anggotanya, salah satu media penting dalam mengarahkan mereka, agar hati mereka lebih mudah bergerak untuk maju adalah kesejahteraan. Banyak cara dan usaha yang dapat dilakukan kepala sekolah dalam rangkah meningkatkan kesejahtearan personil sekolah. Di samping pemberian insentif dan atau gaji 
yang layak, usaha meningkatkan kesejahteraan personel dapat pula dilakukan dengan jalan: ( Lailiyah, N. (2017). Sebagai berikut:

a) Membentuk semacam ikatan keluarga sekolah yang bersifat sosial.

b) Membentuk koperasi keluarga personel sekolah.

c) Mengadakan kegiatan-kegiatan seperti olah raga, diskusi-diskusi yang berhubungan dengan pengembangan profesi guru-guru atau pegawai sekolah.

d) Memberi kesempatan dan bantuan dalam rangka pengembangan karier, seperti kesempatan melanjutkan pelajaran, kesempatan mengikuti penataranpenataran, selama tindakan mengganggu atau merugikan jalannya sekolah.

e) Mengusulkan dan mengurus kenaikan gaji atau pangkat guru-guru dan pegawai tepat pada waktunya sesuai dengan peraturan yang berlaku. Semua yang telah dibicarakan di atas memerlukan adanya kepemimpinan kepala sekolah yang baik dan bijaksana disertai pengawasan dan pembinaan yang tepat dan berkelanjutan.

Pendidikan di Indonesia diatur dengan cara membuat delapan standar minimal yang harus dipenuhi oleh setiap sekolah yang ada (M. Prawiro, 2018). Delapan standar tersebut yakni standar isi, standar kompetensi lulusan, standar proses pendidikan, standar sarana dan prasarana, standar pengelolaan, standar pembiayaan pendidikan,standar penilaian pendidikan, standar pendidik dan tenaga kependidikan (Peraturan Pemerintah Nomor 13 Tahun 2015, Tentang Perubahan Kedua atas Peraturan Pemerintah Nomor 19 Tahun 2005 Tentang Standar Nasional Pendidikan, 2015).

Kualitas/mutu pendidik yaitu pendidik yang profesional, yang tugas utamanya ialah mentransformasikan, mengembangkan, menyebarluaskan ilmu pengetahuan dan teknologi melalui pendidikan dan mampu menghasilkan keluaran lulusan yang memenuhi empat kompetensi peserta didik yaitu kompetensi akademik, kompetensi profesional, kompetensi nilai atau sikap, dan kompetensi untuk menghadapi perubahan. Dan yang dimaksud dengan kualitas/mutu tenaga kependidikan yaitu pegawai yang profesional dimana tugas mereka adalah melaksanakan administrasi, pengelolaan, pengembangan, pengawasan, dan pelayanan teknis, dan memiliki kualifikasi, kompetensi, dan sertifikasi sesuai dengan bidang tugasnya untuk menunjang proses pendidikan pada satuan pendidikan.

Standar Kualitas Pendidik dan Tenaga Kependidikan Standar yang dijadikan parameter atau ukuran tinggi rendahnya kualitas/mutu pendidik dan tenaga kependidikan dalam kinerjanya adalah kompetensinya. Hal ini tercermin dalam PP nomor 19 tahun 2005 pasal 2 (1) bahwa: Standar Nasional: terdiri atas isi, proses, kompetensi lulusan, tenaga kependidikan, sarana dan prasarana, pengelolaan, pembiayaan dan penilaian pendidikan yang harus ditingkatkan secara berencana dan berkala. Standar yang dimaksud adalah suatu kriteria yang telah dikembangkan dan ditetapkan berdasarkan atas sumber, prosedur dan manajemen yang efektif. Sedangkan kriteria adalah sesuatu yang menggambarkan ukuran dan keadaan yang dikehendaki. Secara konseptual, standar juga dapat berfungsi sebagai alat untuk menjamin bahwa progam-progam pendidikan suatu profesi dapat memberikan kualifkasi kemampuan yang harus dipenuhi oleh calon sebelum masuk ke dalam profesi yang bersangkutan. (Rahman, T. (2010).

Abdul Majid mendefinisikan bahwa "kompetensi adalah seperangkat tindakan penuh tanggung jawab yang harus dimiliki seseorang sebagai syarat untuk dianggap mampu 
melaksanakan tugastugas dalam bidang pekerjaan tertentu".Abdul Majid juga mendefinisikan "kompetensi merupakan pengetahuan, ketrampilan, dan nilai-nilai dasar yang direfleksikan dalam kebiasaan berfikir dan bertindak". Sedangkan menurut UU guru dan dosen mengartikan bahwa kompetensi adalah seperangkat pengetahuan, ketrampilan, dan perilaku yang harus dimiliki, dihayati, dan dikuasai oleh guru dalam melaksanakan tugas keprofesionalan. (Rahman, T. (2010).

Pendidik ialah tenaga kependidikan yang berkualifikasi sebagai guru, dosen, konselor, pamong belajar, widyaiswara, tutor, instruktur, fasilitator, dan sebutan lain yang sesuai dengan kekhususannya, serta berpartisipasi dalam menyelenggarakan pendidikan. Sehingga dapat dikatakan bahwa guru adalah pendidik. Sedangkan, Tenaga kependidikan ialah anggota masyarakat yang mengabdikan diri dan diangkat untuk menunjang penyelenggaraan pendidikan (UU Nomor 20/2003, Bab I, Pasal 1, ayat (5) dan ayat (6). Tenaga kependidikan bertugas melaksanakan administrasi, pengelolaan, pengembangan, pengawasan, dan pelayanan teknis untuk menunjang proses pendidikan pada satuan pendidikan (UU Nomor 20/2003, Bab XI, Pasal 39, ayat (1). Tenaga kependidikan meliputi pengelola satuan pendidikan, penilik, pamong belajar, pengawas, peneliti, pengembang, pustakawan, laboran dan teknisi sumber belajar (UU Nomor 20, Tahun 2003, Penjelasan Pasal 39, ayat (1). Standar pendidik dan tenaga kependidikan mencakup: kriteria pendidikan prajabatan, kelayakan fisik maupun mental, serta pendidikan dalam jabatan. Secara khusus tugas dan fungsi tenaga pendidik (Guru dan Dosen).

Di dasarkan pada UU No 14 Tahun 2005, yaitu sebagai agen pembelajaran untuk meningkatkan mutu pendidikan nasional, pengembangan ilmu pengetahuan, teknologi, dan seni, serta pengabdi kepada masyarakat. Dalam pasal 6 disebutkan bahwa: kedudukan guru dan dosen sebagai tenaga professional bertujuan untuk melaksanakan sistem pendidikan nasional dan mewujudkan tujuan pendidikan nasional, yaitu berkembangnya potensi peserta didik agar menjadi manusia yang beriman dan bertakwa kepada Tuhan Maha Esa, berakhlak mulia, sehat, berilmu, cakap, kreatif, mandiri, serta menjadi warga negara yang demokratis dan bertanggung jawab. Dalam menjalankan tugas dan fungsinya secara profesional tenaga pendidik dan kependidikan harus memiliki kompetensi yang diisyaratkan baik oleh peraturan pemerintah maupun kebutuhan masyarakat antara lain:

a) Pendidik harus memiliki kualifikasi minimum dan sertifikasi sesuai dengan jenjang kewenangan mengajar, sehat jasmani an rohani, serta memiliki kemampuan untuk mewujudkan tujuan pendidikan nasional.

b) Pendidik untuk pendidikan formal pada jenjang pendidikan usia dini, pendidikan dasar, pendidikan menengah, dan pendidikan tinggi dihasilkan oleh perguruan tinggi yang terakreditasi. Mereka pun memiliki hak dan kewajiban dalam melaksanakan tugas yaitu: Pendidik dan tenaga kependidikan berhak memperoleh yakni Penghasilan dan jaminan kesejahteraan sosial yang pantas dan memadai, Penghargaan sesuai dengan tugas dan prestasi kerja, Pembinaan karier sesuai dengan tuntutan pengembangan kualitas, Perlindungan hukum dalam melaksanakan tugas dan hak atas hasil kekayaan intelektual., Kesempatan untuk menggunakan sarana, prasarana, dan fasilitas pendidikan untuk menunjang kelancaran pelaksanaan tugas. Pendidik dan tenaga kependidikan berkewajiban yakni Menciptakan suasana pendidikan yang bermakna, menyenangkan, kreatif, dinamis, dan dialogis, Mempunyai komitmen secara profesional untuk 
meningkatkan mutu pendidikan, Memberi teladan dan menjaga nama baik lembaga, profesi, dan kedudukan sesuai dengan kepercayaan yang diberikan kepadanya.

Pendidik dan tenaga kependidikan merupakan seluruh komponen yang terdapat dalam lembaga pendidikan, tidak hanya mencakup guru saja melainkan keseluruhan yang berpartisipasi dalam pendidikan. Jika ditinjau dari unsur jabatan tenaga kependidikan dibedakan menjadi tiga yakni:

a. Tenaga Struktural; tenaga kependidikan yang menempati jabatan-jabatan eksekutif umum (pemimpin) yang bertanggung jawab langsung maupun tidak langsung atas satuan pendidikan (contoh: kepala sekolah, wakil kepala sekolah, urusan kurikulum, kesiswaan, sarana prasarana, dan pelayanan khusus).

b. Tenaga Fungsional; tenaga kependidikan yang menempati jabatan fungsional yaitu jabatan yang dalam pelaksanaan pekerjaannya mengandalkan keahlian akademis kependidikan, (seperti: guru, guru bimbingan penyuluhan atau konseling, pengembangan kurikulum dan teknologi kependidikan, pengembangan tes, dan pustakawan).

c. Tenaga Teknis Kependidikan; tenaga kependidikan yang dalam pelaksanaan pekerjaannya lebih dituntut kecakapan teknis operasional atau teknis administrative, (seperti: laboran, teknisi sumber belajar, pelatih; olahraga, kesenian dan keterampilan. dan petugas TU).

\section{Simpulan}

Meningkatkan Kualitas Pendidik dan Tenaga Kependidikan Pada pengelolaan pendidikan yang sentralistik, sekolah menjadi unit birokrasi dan pendidik sering diposisikan sebagai karyawan birokrasi pemerintah. Sebaliknya pada format pengelolaan pendidikan yang desentralisasikan, sekolah dikonsepkan sebagai unit akademik dan pendidik merupakan tenaga profesional. Supaya mempunyai lulusan peserta didik yang diharapkan maka sekolah harus bisa meningkatkan kualitas/mutu pendidik dan tenaga kependidikannya. Untuk meningkatkan kualitas/mutu pendidik dan tenaga kependidikan setiap sekolah biasanya mempunyai cara yang berbeda-beda, akan tetapi disini penulis akan membahas pengertian kualitas/mutu terlebih dahulu. Kualitas/mutu pendidik dapat lihat dari kualifikasi akademik, kompetensi, sertifikasi sesuai dengan bidang tugasnya, serta sehat jasmani dan rohani, serta memiliki kemampuan untuk mewujudkan pendidikan nasional. Kualifikasi akademik ialah pendidikan tinggi progam sarjana atau diploma empat. Kompetensi pendidik ialah kompetensi pedagogik, kompetensi kepribadian, kompetensi sosial, dan kompetensi profesional.

\section{Daftar Pustaka}

Amka, A. (2021). Manajemen dan Administrasi Sekolah.

Amon, L., Ping, T., \& Poernomo, S. A. (2021). Tugas dan Fungsi Manajemen Pendidik dan Tenaga Kependidikan. Gaudium Vestrum: Jurnal Kateketik Pastoral, 5(1), 1-12.

Azis, R. (2016). Pengantar administrasi pendidikan.

Danuri, P. P., Maisaroh, S., \& Prosa, P. G. S. D. (2020). ADMINISTRASI DAN SUPERVISI PENDIDIKAN.

Fadhila, A. (2020). Administrasi Pendidikan. Padang: Universitas Negeri Padang. 
Hanafiah, M. A. (2017). Supervisi Dalam Administrasi Pendidikan. Hikmah, 14(1), 21-27.

Hendrowati, T. Y. Administrasi Pendidikan. STKIP MUHAMMADIYAH PRINGSEWU LAMPUNG

Humaira, J., \& Afriansyah, H. Pentingnya Administrasi Pendidikan di Indonesia.

Lailiyah, N. (2017). Manajemen Peningkatan Kualitas Personalia di Lembaga Pendidikan Islam. Al-Idaroh: Jurnal Studi Manajemen Pendidikan Islam, 1(2), 130-152.

Mutiani, M., Abbas, E. W., Syaharuddin, S., \& Susanto, H. (2020). Membangun Komunitas Belajar Melalui Lesson Study Model Transcript Based Learning Analysis (TBLA) dalam Pembelajaran Sejarah. Historia: Jurnal Pendidik dan Peneliti Sejarah, 3(2), 113122.

Mutiani, M., Sapriya, S., Handy, M. R. N., Abbas, E. W., \& Jumriani, J. (2021). Pembinaan Etika Peserta Didik Melalui Pembelajaran Tematik-Integratif Di Sekolah Dasar. Edukatif: Jurnal Ilmu Pendidikan, 3(3), 704-709.

Nurhardini, S. (2019). administrasi peranan suvervisi pendidikan.

Paputungan, N. (2020). PELAKSANAAN FUNGSI ADMINISTRASI PERSONALIA PENDIDIKAN DI MADRASAH TSANAWIYAH NEGERI 1 BOLAANG MONGONDO (Doctoral dissertation, IAIN Manado).

Puteri, A. A. Pentingnya Mempelajari Administrasi dan Supervisi Pendidikan.

Rahman, T. (2010). Studi pengembangan kualitas pendidik dan tenaga kependidikan melalui pendidikan dan pelatihan di MA Darun Najah Ngemplak Pati (Doctoral dissertation, IAIN Walisongo).

Sohiron, S. (2016). ADMINISTRASI DAN SUPERVISI PENDIDIKAN.

Subiyakto, B., \& Mutiani, M. (2019). Internalisasi nilai pendidikan melalui aktivitas masyarakat sebagai sumber belajar ilmu pengetahuan sosial. Khazanah: Jurnal Studi Islam Dan Humaniora, 17(1), 137-166.

Uhansyah, U. (2017). Pentingnya administrasi sekolah untuk kemajuan pendidikan. ITTIHAD, 15(27).

Zakhiroh, R. (2017). Pengaruh kinerja tenaga administrasi sekolah terhadap kualitas layanan administrasi non akademik. DIDAKTIKA: Jurnal Pemikiran Pendidikan, 19(2), 59-70. 